CURRENT RESEARCH JOURNAL OF PHILOLOGICAL SCIENCES

(ISSN -2767-3758)

VOLUME 03 ISSUE 01 Pages: 31-35

SJIF IMPACT FACTOR (2021: 5. 823)

OCLC - 1242423883 METADATA IF - 6.925

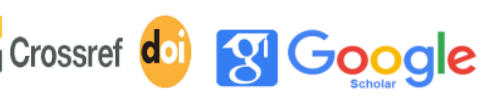

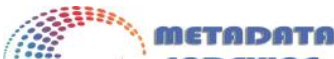

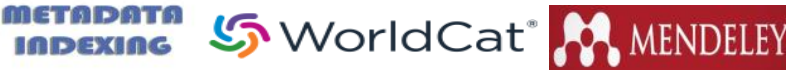

Publisher: Master Journals

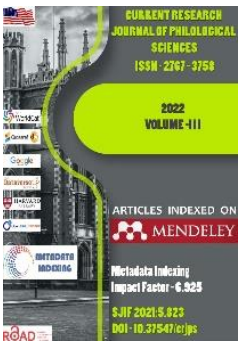

Journal Website: https://masterjournals. com/index.php/crips

Copyright: Original content from this work may be used under the terms of the creative commons attributes 4.0 licence.
Research Article

\section{SEMANTIC FEATURES OF GENDER LEXICAL UNITS OF ENGLISH}

Submission Date: December 23, 2021, Accepted Date: January 3, 2022, Published Date: January 13, 2022

Crossref doi: https://doi.org/10.37547/philological-crjps-03-01-06

Laylo R. Khalilova

Lecturer, Department of “Distance education" Gulistan State University, Uzbekistan

\title{
ABSTRACT
}

This article is about semantic features of gender lexical units in modern linguistics. In everyday speech, the word "gender" is associated with the biological and social differences between women and men. In addition, people might know that languages can have masculine and feminine words. It may seem that grammatical gender is a reflection of natural gender in grammar. We know that in everyday language, gender is not talked about, not even mentioned. In other words, it is not the type of information that is predicated of a referent. It is not often uttered such statements as: 'she's a woman' or 'my computer is a thing'. These sentences are perfectly grammatical of course, and they make sense, but they are not uttered. Or if they are gender nous such as 'woman' or 'man' are not used to convey information about gender but some implicature, often close to stereotype: 'She spends a fortune on perfume. - Well, what do you expect, she's a woman'. In texts we find such utterances as 'She was an extraordinary woman' (where the noun is preceded by an adjective) but not 'She was a woman'. In the first of these two clauses the noun 'woman' is only there to support the extra specification of the adjective ('extraordinary').

\section{KEYWORDS}

Gender, linguistics formation, gender equality, gender inequality, nature of sex, male and female speech, gendermarked lexical units. 


\section{CURRENT RESEARCH JOURNAL OF PHILOLOGICAL SCIENCES}

(ISSN -2767-3758)

VOLUME 03 ISSUE 01 Pages: 31-35

SJIF IMPACT FACTOR (2021: 5. 823)

OCLC - 1242423883 METADATA IF - 6.925

Crossref
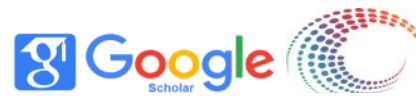

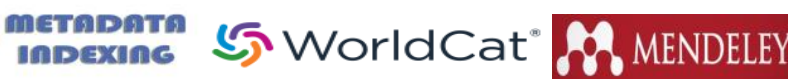

Publisher: Master Journals

\section{INTRODUCTION}

In terms of information structure, this amounts to saying that natural gender is a denotatum that resists focalization. I assume, after Lambrecht (1994), that a canonical clause consists of a subject and a predicate, that the subject represents the topic, what is talked ABOUT, and that the predicate represents the focus. With the focus the speaker comments on the topic. (If I say: 'I am hungry', I am talking about myself, and about myself I add that I am hungry. 'Be hungry' is the denotatum that is focalized). It seems that natural gender is hardly ever focalized. It is not the kind of comment you make on a referent. If natural gender was ever mentioned, that would presumably be when a new character is introduced. Let us take a look at two extracts from the novel where a new character is introduced.

First, at the beginning of the novel, as is most commonly the case:

When the telephone rang, Gill was outside, raking the leaves into coppery piles, while her husband shoveled them on to a bonfire. It was a Sunday afternoon in late autumn. She ran into the kitchen when she heard its shrilling, and immediately felt the warmth of inside enfold her, not having realized, until then, how chilly the air had become.

A person, Gill, is mentioned straightaway. Her gender is not mentioned, at least not explicitly. However the information is unambiguously conveyed, through 1) the proper name 2) the personal pronouns 3 ) the word 'husband' (if she has a husband, she's a woman). Note in this respect that another character is introduced in these first lines of the novel, i.e. the husband. Again, it is not stated that he is a man, but the information is also unambiguously conveyed, this time through the lexical item 'husband', which includes the /+male/ semantic feature. In the following extract, another character is introduced, who is first called a 'stranger'. In the rare cases where natural gender is not obvious, we are confronted with embarrassing situations. We all know that it is not socially acceptable to ask someone: 'Are you a man or a woman?' and we do everything we can to avoid this situation. In his discussion of pragmatic presupposition, Robert Stalnaker (1973) quoted in Lambrecht (1994) mentions a well-known type of conversational exchange. The situation is the following. A asks of B's baby-girl: 'how old is he?' and B answers 'She is ten months old'. The first speaker thinks that the baby is a boy when in fact it is a girl. Lambrecht, who borrows this example to Stalnaker and analyses it along the same lines, argues that when $B$ replies 'She's ten months old', she pretends that the fact that the baby is a girl is a shared presupposition, in order to re-establish a normal situation for a conversation. For Stalnaker this goes to confirm that a topic (normally expressed in subject position) is typically presupposed. I do not dispute that, but I would like to point out that this act of pretending would not take place in another situation. In this example, the speaker pretends that there is a common background because the sentence 'Oh it's a girl' feels awkward. Let's imagine a similar situation, where a wrong assumption is made about another type of referent (not a human being). If someone assumes that I recently moved in a house, when actually I moved in a flat, and if that person asks me 'How big is your new house?' I'm not likely to answer 'My flat is rather big'. I would probably start with explicitly correcting the wrong assumption, and then I would move on. So I would say something like: 'Oh it's a flat actually. And yes, it's quite big'. Robert Stalnaker's example reveals not only that a subject is typically presupposed, but also that natural gender is not easily predicated of a 
CURRENT RESEARCH JOURNAL OF PHILOLOGICAL SCIENCES

(ISSN -2767-3758)

VOLUME 03 ISSUE 01 Pages: 31-35

SJIF IMPACT FACTOR (2021: 5. 823)

OCLC - 1242423883 METADATA IF - 6.925

Crossref
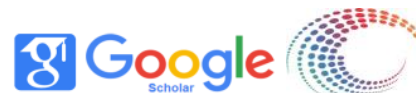

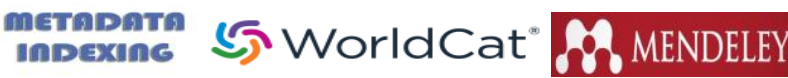

Publisher: Master Journals

referent. Gender is a denotatum that is conceptualized as taken for granted.

Again, the notion of gender is conveyed, but indirectly, via 'her' and the proper name 'Imogen'. Note that this feels perfectly normal and cannot be ascribed to any stylistic effect, whereby something would be felt to be missing. The reader is not particularly surprised that natural gender is not predicated of the characters. In fact there is nothing typical of literature here, the same would hold for a real-life introduction: when we introduce someone, gender is not what we mention. We may say, for example: 'This is Catherine, she's my new neighbour', but not *'This is Catherine, she's a woman'. Natural gender is of course relevant but is treated as taken for granted.

The reason for the fact that natural gender resists focalization cannot be that gender is not relevant. It is of course extremely relevant in our daily lives, in terms of social interaction, reproduction, survival of the species... It is in fact so relevant that it is the first predication to be made about a person: when a baby is born one says: 'It's a boy' or 'It's a girl'. The next stage is that the baby is given a (first) name, which very often (although not always) includes the $1+$ MALE/ or /+FEMALE/ semantic feature - Then natural gender is not supposed to be discussed, or even mentioned any more, at least, by adults. It is taken for granted.

It has to be noted, however, that one may find gender predicated of a person in children's conversations: 'I can't wear those clothes, I'm a boy / girl'; 'he used a pink pencil, he's a girl'. Adults, however, do not seem to have these conversations. And even when children do, this does not mean that children are not aware of their gender. With 'He's a girl' the child means that he knows perfectly well that his/her interlocutor is a boy, but that in his (stereotyped) opinion he behaves like a girl. Or when a girl says 'I'm a girl' she knows that her interlocutor knows that, she is only justifying a refusal to wear something. It is not a 'first' predication; in other words gender is not supposed to be new information.

The structure of the lexicon offers other indications that natural gender is conceptualized as 'taken for granted'.

The missing nouns

The English lexicon seems to be organized in such a way that there is no noun which means 'male human being' or 'female human being', that is that holds for a male or female human being throughout his or her life. The noun 'woman', for instance, denotes a female human animate, but further categorizes the person as an adult. Gender nouns such as 'man', 'woman', 'boy' or 'girl' all add to the gender specification an extra semantic feature. In other words, where human beings are concerned, there is no noun which expresses natural gender only. I can only conjecture that the reason for this is that gender is construed as such a basic specification that it is always back-grounded in order for the noun to convey another feature of the referent. This is another indication that gender is construed as 'taken for granted'.

Dictionary definitions of gender nouns make this phenomenon clear. In the Shorter Oxford English Dictionary the first definition of 'woman' is: 'An adult female person, as opposed to a man or girl or both'. The 'adult' feature is also present in the other senses of the word listed in the dictionary, e.g. 'servant' or 'lover', even if it remains implicit in the definition. The only meaning of that word that may seem to contradict our view is the third one, where the noun is used in its generic sense: The female human person, esp. viewed as a type; the female sex.' However I would argue that even there 'woman' does not denote all human 


\section{CURRENT RESEARCH JOURNAL OF PHILOLOGICAL SCIENCES}

(ISSN -2767-3758)

VOLUME 03 ISSUE 01 Pages: 31-35

SJIF IMPACT FACTOR (2021: 5. 823)

OCLC - 1242423883 METADATA IF - 6.925

feminine beings but only adults, as suggested by the two examples which illustrate that meaning: 'DRYDEN Woman's a various and changeful Thing! S. RICHARDSON Woman is the glory of all created existence: - but you, madam, are more than woman!' In both examples the noun 'woman' occurs in the context of (love) relationships between men and woman, i.e. adult human beings. Note in this respect the form of address 'Madam' in the second example, which includes the /+ADULT/ semantic feature and suggests that when the speaker uses the noun 'woman' he is thinking of adult female human beings, rather than of all female human beings.

The nouns 'male' and 'female' do not qualify to fill the gap in the lexicon, as 1) they are derived from adjectives; 2) they do not only denote human beings but also animals; 3) they are rarely used for humans anyway (we do not normally say: 'my neighbour is a female of extraordinary beauty' or 'a female came round to see you').

The missing pronouns

Yet another sign that gender is construed as always taken for granted is that there is no way to ask what something is if we do not even know whether we are talking of a thing or a human. To make things clearer, let us imagine the following situation. I stumble on something in the dark, which could either be a thing or a person, and I want to identify that something. If I ask a question, I have to choose between 'What is it?' and 'Who is it?' i.e. I have to pre-suppose a basic categorization of the referent, even though, paradoxically, I am in a context where I seek identification. There seems to be no way to phrase what I want to phrase in this situation. In the same way that there are missing nouns there is a missing interrogative pronoun.
Similarly, there is no pro-form that subsumes 'something' and 'somebody'. If I make out a shape in the distance and do not know whether it is a thing or a person, I have no way of saying 'I see something or somebody'. There is no pronoun that cumulates (or neutralizes) the /+HUMAN/ and /-HUMAN/ semantic features. The pronoun must select a feature, which is that of the category. The same applies to 'anyone' / 'anybody' and 'anything'. There is no term that can express the idea that I cannot see anyone or anything. The referent has to be previously categorized. This again shows that natural gender (here taken as the human vs. non-human distinction) has to be taken for granted. Gender is construed as being always already known, a referent is supposed to have been previously categorized.

After these incursions into the domains of pragmatics and lexical semantics, let us now sum up what makes the conceptualization of natural gender, i.e. what we see as inherently linked with natural gender. The following list is not necessarily exhaustive. Natural gender involves a two-term opposition (either masculine vs. feminine or human vs. not human); it is an objective piece of information; it is not supposed to be predicated of a referent; it is taken for granted (or, in other words: it is supposed to be always already known); it is stable (i.e. it does not change), this last characteristic being the reason why it is taken for granted. One may also add that natural gender is not gradable - I will come back to this characteristic. Note that what constitutes the concept may be a simplified version of what we experiment in our daily lives. Although in real life gender may, in some rare cases, change (some individuals may switch from male to female or vice-versa), the most usual and typical (i.e. entrenched) situation is that gender does not change (there is no switching between human and not human), and that is what is selected in the concept 
CURRENT RESEARCH JOURNAL OF PHILOLOGICAL SCIENCES

(ISSN -2767-3758)

VOLUME 03 ISSUE 01 Pages: 31-35

SJIF IMPACT FACTOR (2021: 5. 823)

OCLC - 1242423883 METADATA IF - 6.925

Crossref dol gु' Google

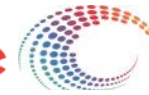
metaparn (5) WorldCat

Publisher: Master Journals

\section{CONCLUSION}

The gender of pronouns can of course be in keeping with the natural gender of the referent. In fact this is the most common situation in English. But when natural gender and grammatical gender differ, gender reflects stages of categorization.

It is perhaps not so surprising that gender should express categorization, particularly the kind of categories denoted by nouns. In our experience we make a difference between humans (ourselves) and non-humans, and between males and females. Moreover, gender is an all-or-nothing opposition, particularly apt to express in a metalinguistic way the type of categorization expressed by nouns.

\section{REFERENCES}

1. BARSALOU, L., C. WILSON and W. HASENKAMP (2010). 'On the vices of nominalization and the Virtues of Contextualizing', in B. MESQUITA, L. FELDMAN BARRETT, \& E. SMITH (eds.), The Mind in Context. New York: Guilford Press, 335-360.

2. STALNAKER, R. (1973). 'Presupositions', Journal of Philosophical Logic 2, 447-457.

3. BIBER, D., S. JOHANSSON, G. LEECH, S. CONRAD and E. FINEGAN (1999). Longman Grammar of Spoken and Written English. London: Longman.

4. BOLINGER, D.L. (1977). Meaning and Form. English Language Series, 11. Longman: London.

5. CORBETT, G. (1991). Gender. Cambridge : Cambridge University Press.

6. IXON, R.M.W. (1982). Where have all the adjectives gone? And other Essays in Semantics and Syntax. Berlin and New York: Mouton.

7. DIXON, R.M.W. (1986). 'Noun Classes and Noun Classification in Typological Perspective', in
CRAIG C. (ed.) Noun Classes and Categorization. Amsterdam: John Benjamins, 105-12.

8. DIXON, R.M.W. (2002). Australian languages: their nature and development. Cambridge: Cambridge University Press.

9. HUDDLESTON, R., G. PULLUM et al. (2002). The Cambridge Grammar of the English Language. Cambridge: Cambridge University Press.

10. KATZ, J.J. and J.A. FODOR (1963). 'The structure of a semantic theory', Language 39: 170-210.

11. LAKOFF, G. (1987). Women, Fire and Dangerous Things. Chicago : University of Chicago Press.

12. LAMBRECHT, K. (1994). Information Structure and Sentence Form. Topic, Focus and the Mental Representation of Discourse Referents. Cambridge : Cambridge University Press.

13. Shorter Oxford English Dictionary on Historical Principles. Fifth edition (2002). Oxford: Oxford University Press.

14. TAYLOR, J.R. (2003). Linguistic Categorization: Prototypes in Linguistic Theory. Oxford : Oxford Clarendon Press.

15. WIERZBICKA, A. (1988). 'What's in a noun? or: How do nouns differ in meaning from adjectives?)' in WIERZBICKA A., The Semantics of Grammar. Amsterdam: John Benjamins Publishing Company, 463-497. 